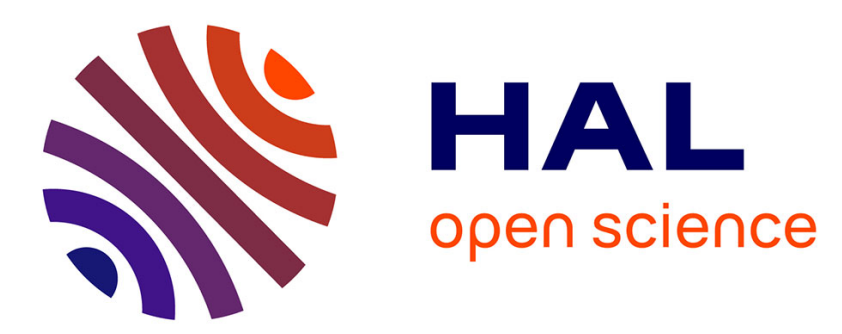

\title{
Redistribution and indirect effects of transport policy and projects in Jules Dupuit's thought

\author{
Philippe Poinsot
}

\section{To cite this version:}

Philippe Poinsot. Redistribution and indirect effects of transport policy and projects in Jules Dupuit's thought. Transport Policy, 2018, Jules Dupuit: Secret Origins of Modern Transportation Science, 70, pp.40-45. 10.1016/j.tranpol.2018.01.003 . hal-01689846

\section{HAL Id: hal-01689846 https://hal.science/hal-01689846}

Submitted on 22 Aug 2019

HAL is a multi-disciplinary open access archive for the deposit and dissemination of scientific research documents, whether they are published or not. The documents may come from teaching and research institutions in France or abroad, or from public or private research centers.
L'archive ouverte pluridisciplinaire HAL, est destinée au dépôt et à la diffusion de documents scientifiques de niveau recherche, publiés ou non, émanant des établissements d'enseignement et de recherche français ou étrangers, des laboratoires publics ou privés. 
Redistribution and indirect effects of transport policy and projects in Jules Dupuit's thought

Philippe Poinsot

Assistant professor, Laboratoire Ville Mobilité Transport (LVMT, UMR-T 9403), Ecole des Ponts, IFSTTAR, UPEM, UPE

Philippe.Poinsot@u-pem.fr, Philippe.Poinsot@enpc.fr

Poinsot, P. (2018). Redistribution and indirect effects of transport policy and projects in Jules Dupuit's thought. Transport Policy, 70, pp. 40-5. 
"State intervenes and should ever intervene only when public interest is engaged" (Dupuit, 1862a, $p$. 645)

\section{Introduction}

Cost-benefit analysis (CBA) is today regarded as one of the main methods for the evaluation of transport policy and projects (Thomopoulos et al., 2009; Browne and Ryan, 2011; Martens, 2011; van Wee, 2011). In particular, CBA would enable decision makers to evaluate investment in transport infrastructure and determine transport policy actions that are in line with public interest. For instance, in France, the clarification of the conditions of the use of CBA for transport decisions has been subject of many reports and guides, the most wellknown being Boiteux $(1994,2001)$ and Quinet (2013).

CBA is also the subject of many criticisms and debates from civil society, public decisionmakers and economists. One of these debates concerns the issue of equity and social justice which becomes important in transport policies and transport projects (see Di Ciommo \& Shiftan, 2017 and Litman, 2002). Equity poses a major challenge to CBA as it is usually applied because the redistribution of wealth and indirect effects are not taken into account.

CBA is rooted in the debates between engineers of the Corps des Ponts et Chaussées in the nineteenth century (Etner, 1987). The work of Jules Dupuit on the measurement of "utilité publique $^{\prime 1}$ (1844 [1952], 1849 [1962], 1853) constitutes a major break with the method used until then by the engineers (Ibid; Ekelund \& Hébert, 1999). After finishing his studies in Ecole Polytechnique in 1822 and Ecole des Ponts et Chaussées (1824), Dupuit becomes Chief Engineer of the Marne in 1840 and the Maine-et-Loire in 1844 (Chatzis, 2009; Reverdy, 2002;

\footnotetext{
${ }^{1}$ The concept of "utilité publique" in Dupuit's work is different from the English expression "public utility": while the latter means an organization (company or administration) providing a public service, the former refers to a criterion to increase the wealth of society (see section 2.2). In this paper, I will use Dupuit's definition of public utility. This remark was suggested to me by one of the referees, whom I would sincerely like to thank.
} 
2016). Then, he meets the French liberals ${ }^{2}$ of the nineteenth century such as Henri Baudrillart, Joseph Garnier, Gustave de Molinari..., writes articles for Journal des economists and takes part in many debates at the Société d'économie politique on many subjects such as food crises, property rights, free-trade... (Simonin \& Vatin, 2002 and 2016; Poinsot, 2011). Today, he is commonly known as a member of the French tradition of the engineereconomist and is recognized for his contribution to the field of public economics and transport economics through his articles on CBA and demand curve.

In this article, I analyze Dupuit's position on redistributions of wealth and indirect effects generated by transport policy and infrastructure and its relationships with collective choices. In other words, should these effects be taken into account to make collective choices according to Dupuit? This paper is based on a work in history of economic thought in which I analyzed all Dupuit's works in order to understand the consistency of his economic analysis (Poinsot, 2011). Unlike Dupuit's scholars (Ekelund \& Hébert, 1999; Etner, 1987), I showed that public interest 3 and public utility are two different concepts: while the former is the objective of society which is to maximize the welfare of the nation and protecting all natural rights (except natural liberty), public utility is a criterion that political economy indicates to the legislator in order to increase wealth which is one determinant of the welfare of society ${ }^{4}$. In this article, I will argue that this distinction is directly at stake when the engineer discusses the issue of redistributions of wealth and indirect effects. This leads Dupuit to distinguish between two points of view: the engineer-economist's point of view which is only concerned by public utility and the legislator's point of view which is broadly concerned by general interest.

\footnotetext{
${ }^{2}$ The term "liberal" is used here in the French sense of the word, referring to the nineteenth-century economists who believed that free market conditions were more effective than state intervention in the economy.

${ }^{3}$ Dupuit uses public interest and general interest as equivalent terms. For instance, concerning inheritance, Dupuit claims that: "[People who ask for unlimited freedom for inheritance] says: you grant the owner during his (her) lifetime the absolute right to dispose of his (her) property; to prevent him (her) from doing after his (her) death what he (she) could have done during his (her) life? - It is then that the guarantee of the good use misses, and that no longer being retained by his (her) personal interest, in agreement with general interest [intérêt général], the owner could engage in posthumous eccentricities contrary to public interest [intérêt public]" [(1861b), p. 627]. Echoing Dupuit, I will consider the terms 'general interest' and 'public interest' to be synonymous.

${ }^{4}$ For instance, this distinction between general interest and public utility is essential to understand the consistency of Dupuit's position on the operation of railroads. For more details, see Poinsot (2016).
} 
The paper is organized as follows. In section 2, I specify the difference between general interest and public utility in Dupuit's thought and show that this leads to the necessity to distinguish between the points of view of the legislator and of the engineer-economists. In section 3, I specify Dupuit's positions on redistributions of wealth and indirect effects generated by transport policy and infrastructures. In particular, I argue that according to Dupuit the engineer-economist should not take into account these effects whereas the legislator should be concerned by them if they might decrease the quantity of wealth and the welfare of society in the long run.

\section{General interest and public utility in Jules Dupuit's thought}

Public interest holds a central place in Dupuit's thought which surely stems from his education at the Polytechnique and the Ecole des Ponts et Chaussées. For instance, Mosca states that the "French civil engineers felt themselves to be the standard bearers of a privileged mission: that of serving and defending the interêt general; all that has ever been written about them testifies to their dedication to this aim" (1998, p. 256). Unlike the secondary literature which interprets public interest as a synonym of public utility, I argue that they are two different concepts. In particular, general interest is the respect of the objective of society and it corresponds to the 'legislator's point of view' (1.1) while public utility is only a criterion that legislator should follow to increase the wealth of society and it corresponds to what may be named 'the engineer-economist's point of view' (1.2).

\subsection{General interest and the legislator's point of view}

For Dupuit, general interest consists of achieving the goal of society which is to maximize the welfare of the nation and protecting all natural rights, except natural liberty. Indeed, he states that laws are enforced in order "to provide the maximum possible overall welfare for all of the individual members of society, by respecting - insofar as this goal allows - their liberties and their natural rights, which are in themselves among the most precious forms of

\footnotetext{
${ }^{5}$ For more details on the reference to public interest in the engineering tradition, see Etner (1987), Grall [(2004), p. 31], Mosca (1998) and Smith (1990).
} 
wealth" (Dupuit, 1861b, p. 639). In the same article, he adds that society "can only exist if some [positive] laws or conventions adjust the interaction of its members and the use of some objects, and restrict the liberty and the natural rights of individuals" (Ibid.).

In order to clarify general interest in Dupuit's thought, it is necessary to specify his analysis of natural rights and his conception of welfare.

First, with regard to natural rights, contrary to conventional readings (Vatin, 2002), Dupuit does not reject the existence of natural rights. ${ }^{6}$ They are four natural rights for him: i. selfownership (body, faculties and labor); ii. self-defense; iii. natural liberty; and iv. the respect of free contracts and agreements ${ }^{7}$. Dupuit differentiates between natural liberty and the other natural rights (self-ownership, self-defense, the respect of free contracts and conventions). For him, lawmakers may restrict individual liberties to increase the welfare of society. Indeed, by entering society, humans have given up their natural liberties: it "is not to be freer but to be happier that humans gather in society" (Dupuit, 1862b, p. 741). He adds that "to ask for an absolute, radical [and] complete liberty is to ask for the state of nature. [We must] accept the need for laws for the sake of public interest" (1861b, p. 636). The engineer gives the example of restrictions on hunting and fishing at certain times of the year: "Society has the right to repress... what it is harmful for society. It is not immoral to catch salmon over the winter: this had always been allowed; however, it has just been prohibited because it is now thought that this fishing could harm the production [and so the welfare of society]" (1863a, p. 745). Although the legislator may restrict individual liberties, Dupuit states that only an increase in the welfare of society justifies an infringement of them. ${ }^{8}$

Unlike natural liberty, the legislator may not restrict the other natural rights (self-ownership, self-defense, the respect of free contracts and agreements). This might be illustrated by Dupuit's position on the need for accompanying measures following changes to the legislation. On the basis that laws are enforced to maximize the welfare of society, he argues

\footnotetext{
${ }^{6}$ Dupuit [(1855), p. 564; (1861a), p. 583; (1862a)]. For a discussion of this point, see Poinsot (2010) and [(2011), pp. 69].

${ }^{7}$ On this point, Dupuit is opposed to the French liberals of his time (Bastiat, Molinari, Garnier...) on property rights. For him, the latter is not a natural right and should be allocated according to public utility. See Poinsot (2010, 2011); Sagot-Duvauroux [(2002a), (2002b), (2016)]; Sigot (2010) and Vatin (2002).

${ }^{8}$ For instance, Dupuit rejects corporations because they lead to the decrease of both civil liberty and the welfare of society (Ibid., pp. 625-6).
} 
that "if experience, if the comparison with what is happening elsewhere... leads... [society] to recognize that it has made a mistake, it changes its legislation, but it does not change its goal [the welfare of the nation]" (1861b, p. 633). So in response to changes in legislation that will undermine existing contracts, which are supposed to meet the self-ownership principle, ${ }^{9}$ Dupuit argues that these changes are legitimate if, and only if, they are balanced by equivalent compensation: "any owner of any form of property by virtue of a [precedent of positive] law, may only be deprived of said property on the condition that [s] he is granted an equivalent [indemnity]. This is a form of natural right" (Ibid.; see also 1861a, pp. 597-8). Compensation can either take the form of a transitional period (for instance, Dupuit's position on free-trade; Dupuit, 1861c, pp. 415-7), which allows the individual to make provisions in accordance with his interests, or the payment of monetary compensation to individuals whose economic conditions have deteriorated (1861b, p. 633). ${ }^{10}$

Second, although Dupuit never attempts to clarify the nature of welfare, some of his statements suggest that he sees welfare as the satisfaction of human needs. This is the perspective from which he justifies the use of average life-expectancy as an index of the welfare of society (Dupuit, 1865). ${ }^{11}$ Indeed, he claims that the "average life expectancy may be considered as the true thermometer of the welfare of populations" (Ibid., p. 349), because "in places where humans live for a long time, they are certainly more comfortable and their needs are better satisfied" (Ibid., pp. 348-9). In other articles, he considers that welfare lies in the fulfillment of needs, desires (see for instance 1861c, p. 420) and enjoyments (1861b, p. 619). He seemed to use the three terms indifferently, as exemplified for instance in the following extract from an unpublished manuscript:

\footnotetext{
"Human desires may be considered to be countless and insatiable; humans spend their lives desiring and seeking to fulfill these desires; to this point, no special distinction should be drawn between human and animal, except for the nature, the number and the variety of desires; the animal also has needs [...]" (Dupuit, 2009, p. 53).
}

Thus, welfare is the satisfaction of human needs, desires and enjoyments (Poinsot, 2011).

\footnotetext{
${ }^{9}$ This assumption is implicit in Dupuit's analysis: indeed, he absolutely refuses any compensation for slave owners because slavery violates natural rights.

${ }^{10}$ For a more in-depth discussion of Dupuit's position on this point, see Poinsot [(2011), pp. 126-9].

${ }^{11}$ There are two indexes of the welfare of society in Dupuit's work: the average life-expectancy (1865) and the proportion of intellectual workers in population [(1861c), pp. 455-7]. For a discussion of these two indexes, see Poinsot [(2011), pp. 231-49].
} 
In previous works (Poinsot, 2010, 2011), I have shown that for Dupuit the welfare of society depends on wealth and the level of population. To increase the welfare of society, the legislator has to raise wealth, which is all goods and services that satisfy human needs. But, how does the legislator know if laws increase wealth? By relating the welfare of society to wealth, Dupuit gives political economy and public utility an important place in public decisions (Dupuit, 1861b, p. 631).

\subsection{Public utility and the engineer-economist's point of view}

Public utility is different from public interest since it is only related to one determinant of the welfare of society, which is wealth. For Dupuit, public utility is an impartial criterion that should be followed by the legislator in order to increase the wealth of society. It provides the solution "to every problem of wealth appropriation and many other economic questions" (1861b, p. 638). For instance, it may solve "the question of taxes, which is much better established and allocated if it does not harm the wealth [of the nation] [...] [or moreover], the question of the coalition or the association of certain interests which should only be authorized on the condition that it does not harm the public interest" (Ibid., footnote 49).

The engineer has said more about public utility in his famous articles on the measurement of public utility (1844 [1952], 1849 [1962], 1853). At the beginning of "On the measurement of the utility of public works" (1844 [1952]), he claims that:

\footnotetext{
"Legislators have prescribed the formalities necessary for certain works to be declared of public utility; political economy has not yet defined in any precise manner the conditions which, these works must fulfill in order to be really useful; at least, the ideas which have been put about on this subject appear to us to be vague, incomplete, and often inaccurate. Yet the latter question is more important than the former; enquiries - be they ever so numerous - , laws and ordinances will not make a road, a railway or a canal useful if it is not so already. The law ought merely to confirm the facts demonstrated by political economy. How is such demonstration to be made? Upon what principles, upon what formula, does it rest? How, in a word, is public utility to be measured?" (1844, p. 205 [1952, p. 83]).
}

This issue is in line with the concerns of the engineers of the Corps des Ponts et Chaussées from this time. Indeed, in response to what they consider to be arbitrary in the decisions to build transport infrastructures under the Emperor Napoleon Bonaparte, the engineers try to develop rational method to make collective choices. Their method is based on the comparison of the costs and the benefits of a transport infrastructure (Etner, 1983, p. 1021 
and p. 1987, pp. 149-50; Ekelund \& Hébert, 1999, pp. 74-6; Grall, 2004). For measuring benefits, the method at this time is the one of another engineer, Henri Navier, which is based on the measurement of utility of Jean-Baptiste Say by the exchange value, or the market price. Then, public utility is measured by the difference between transport costs.

Based on the reformulation proposed by Pellegrino Rossi of 'use value' and 'exchange value' in 'direct utility' and 'indirect utility' (Béraud, 2005; Grall \& Vatin, 1998, 2002 and 2016), Dupuit is opposed to the method of the engineers to measure public utility. In particular, two criticisms are formulated by Dupuit: first, one should take into account production costs and not only transport costs; the second criticism concerns the measurement of benefits by market price.

First, it is necessary to take into account the difference between production costs (including transport costs but also, for instance, the cost of extraction stones) and not only the difference between transport costs. At this time, the engineers measure public utility by the difference between transport costs. To assess the utility of the improvement of an existing transport infrastructure, they compare the initial cost - before the improvement - of the transport with the anticipated cost because of this improvement. If we take the case of a new transport infrastructure, they compare the anticipated cost of transporting a good on that new route and the cost on the nearest transport infrastructure, whatever the infrastructure concerned. Dupuit criticizes this method since the comparison should be made on the total production costs. Indeed, the cost of transporting, for example, one ton of stone per road may be higher than a canal, but the road may have a higher public utility, by allowing access to a quarry where the extraction of the stone is easier, thus reducing the cost of extraction.

The second criticism relates the measurement of utility and benefit by the market price which imply an overvaluation of the public utility of transport infrastructure. For Dupuit, market price is only a minimum and not the measure of the utility or benefit: if an individual buys a good in spite of its price, it is because for him the benefit to consume it is at least equal to this price. He illustrates this point by the following metaphor: 


\begin{abstract}
"If you take the above figure as the measure - and not as the lower limit - of a quantity the exact magnitude of which you do not know, you are acting like a man who, wishing to measure the height of a wall in the dark and finding that he cannot reach the top with his arm raised, says: 'This wall is two meters high, for if it were not, my hand would reach above it'. Now, if you say that the wall is at least two meters in height, then we are agreed; but if you go so far as to say that this is the actual measurement, then we are no longer agreed. In daylight, and equipped with a ladder, you will perceive that our alleged two-meter wall is fifty meters high" (1844, pp. 206-7 [1952, p. 84]).
\end{abstract}

The measurement of utility by market price implies an overvaluation to the public utility of a transport infrastructure. For the engineers, a decrease in transport costs would increase the number of goods transported. Until then, there is no difficulty (although production costs have to be taken into account rather than transport costs). But the problem arises from the fact that they attribute the same utility to the new goods transported as goods formerly transported. For instance, imagine that one have to assess the public utility of the improvement of a transport infrastructure (Table 1). The initial traffic is 10 tons of freight per year and the price is 5 euros per ton; then, the public utility of transport infrastructure for the initial traffic is 50 euros. The improvement of the infrastructure leads to an increase of 20 tons of freight per year, which would imply 30 tons per year after the improvement. As the price is always 5 euros per ton, the engineers' method implies that the new traffic has an utility of 100 euros for 20 tons; then, the public utility of the infrastructure after the improvement is 150 euros for 30 tons. Now, for Dupuit, this method overstates the public utility since for the new traffic, the benefit is not of 5 euros per ton, but it is between 0 and under 5 euros. As a result, the public utility of the transport infrastructure after the improvement would be between 50 and under 150 euros for 30 tons.

Table 1: Comparison of engineers' and Dupuit's methods to assess public utility

\begin{tabular}{|c|c|c|c|}
\hline & Traffic & $\begin{array}{c}\text { Engineers' method } \\
\text { (per traffic unit) }\end{array}$ & $\begin{array}{c}\text { Dupuit's method } \\
\text { (per traffic unit) }\end{array}$ \\
\hline Initial traffic & 10 & 5 & 5 \\
\hline New traffic & 20 & 5 & {$[0,5[$} \\
\hline $\begin{array}{c}\text { Total traffic after the } \\
\text { improvement }\end{array}$ & 30 & & {$[50,150[$} \\
\hline \multicolumn{2}{|c|}{ Public utility (total benefits) } & 150 & \\
\hline
\end{tabular}

For Dupuit, the measurement of utility (or benefit) is not the market price - which is only a minimum - but the maximum sacrifice that an individual is willing to pay in order to get a good, or what we name today "the willingness to pay". Indeed, why "is the bottle of wine 
purchased at 15 sous? It is because the buyer finds at least an equivalent utility in it; for, in spite of the tax, he is at perfect liberty to buy it or not to buy it" (1844, p. 208 [1952, p. 85]). And Dupuit adds that to "sum up, political economy has to take as the measure of the utility of an object the maximum sacrifice which each consumer would be willing to make in order to acquire the object" (1844, p. 213 [1952, p. 89]).

Thus, in Dupuit's thought, general interest and public utility are two different concepts. The former is the objective of society which means that it is more global than public utility since it is concerned by increasing the welfare of society as well as protecting natural rights other than natural liberty. Public utility is only a criterion for assessing whether or not public decisions rise wealth, which is only one determinant of the welfare of society (see p. 7). Then it is necessary to distinguish between the point of view of the legislator which is concerned by the welfare of society and general interest, and the engineer-economist's point of view which is only concerned by public utility and the wealth of society. These two different points of view is also at stake when Dupuit discusses the issue of taking into account the redistribution of wealth and indirect effects of transport policy in collective choices.

\section{Should we take into account the redistribution and indirect effects in CBA and public decisions?}

The issue of the redistribution of wealth and indirect effects and the distinction between the point of view of the engineer-economist and the one of the legislator appear in Dupuit's articles on the measurement of public utility (1844 [1952], 1849 [1962], 1853). For him, the engineer-economist should not be concerned by the redistribution of wealth and indirect effects since they do not have impacts on the public utility of a transport infrastructure whereas the legislator should take into account these effects because they may have negative impacts on the quantity of wealth and the welfare of society in the long run (2.1). However, in these three articles, Dupuit does not provide many elements on the conditions that are necessary to justify a compensation of these redistribution of wealth by the legislator. A look at the other works of Dupuit enables this clarification (2.2). 
3.1. Redistribution and indirect effects in the articles on the measurement of public utility $(1844,1849,1853)$

For Dupuit, from the point of view of the engineer-economist, the only relevant criterion is the deadweight loss, whatever the redistribution and indirect effects are. As Maneschi noted it (1996, p. 420), "distributional changes do not cause any change in 'utility' because Dupuit restricted the use of this term to the direct impact of the project on commodity flows".

Concerning the issue of the redistribution of wealth, Dupuit claims that the problem of a high toll on a mean of communication is not the redistribution of wealth from the consumers to the transport infrastructure operator that it implies. Indeed, if "the toll had no other result [than the increase in the profit of the operator] [...], we might say it has no effect on public wealth other than to change its distribution" (1849, p. 280 [1962, p. 12]). But it is the "dead loss for everybody" (1849, p. 277 [1962, p. 12]) due to the high toll, or what Dupuit names a "utility lost, which corresponds to the number of crossings which would be made if the toll were abolished and are not made at the existing rate" $(1849$, p. 277 [1962, p. 9]). In other words, what bothers Dupuit on a high toll is not that what we name today the "consumers' surplus" ("utilité relative" in Dupuit's words) are low but rather that it implies a deadweight loss and a decrease of the public utility of the infrastructure. This is also for this reason that for him the optimal pricing is perfect price discrimination since it deletes the deadweight loss and maximizes the public utility of the transport infrastructure $(1849$, p. 280 [1962, p. 12]).

As regards the issue of indirect effects generated by the construction or the improvement of a transport infrastructure, Dupuit questions the relevance of integrating them in CBA. For instance,

"It often happens [...] that when the cost of production of an article falls, competition causes the price of the same commodity produced by a different method to fall to the same level, as it does also for similar commodities. Thus, coal is carried by canal [...] [which, due to] competition [...] [implies] a fall in the price of wood, which the canal does not carry" (1844, p. 226 [1952, p. 98]).

For Dupuit, these indirect effects should not be taken into account in the measurement of public utility of transport infrastructures because they "might equally well have been obtained by a simple legislative measure" (1844, p. 227 [1952, p. 99]). For instance, imagine 
the case of the construction of a canal that would not transport any goods but which would have the effect of encouraging the producers of wood, iron... of a region to lower their prices in order to retain their position in the market. Dupuit states that "it is evident that the utility due to this fall of price and thereby enlarged consumption, cannot be attributed to the canal, which, carrying nothing, is but a fiction, so to speak, and the course of which could be replaced by a line of stakes." (1844, p. 227 [1952, p. 99]). So, taking into account the indirect effects in the measurement of public utility of the infrastructure, we do not know if the increase in public utility derives from the construction of the transport infrastructure or if it results from other factors such as the increase of the level of competition. From the engineer-economist's point of view, what is important is whether the construction of the transport infrastructure increases the quantity of wealth of society. And its objective is not to take into account all the impacts on the welfare of society since the latter is the concern of the legislator. Dupuit concludes that:

"Therefore when measuring the utility of public undertakings only those commodities must be included, to the production of which the undertaking contributes directly. When the method of evaluation outlined above is applied to those commodities, one may be sure not only of omitting nothing which should be included, but also of counting in nothing which should be left out" (1844, p. 228 [1952, p. 100]).

As Béraud points out (2006), Dupuit's position on the indirect effects leads to the conclusion that he reflects in partial equilibrium. This is on this point that Dupuit is criticized by another engineer of Ponts et Chaussées, Bordas (1847, pp. 91-2), a criticism which will be taken up later by Léon Walras.

Unlike the engineer-economist who may not take into account neither the redistribution of wealth nor the indirect effects of a transport infrastructure, the legislator who is concerned by general interest and the welfare of society should be taken them into account. Indeed, Dupuit states that:

\footnotetext{
"When we say that we are not to take them into account [the redistribution of wealth and indirect effects], we are speaking only with respect to the calculation of utility. The state, on the contrary, must concern itself very seriously with them. A new means of communication is opened; whilst it has a utility of 10 million for society as whole, yet it causes one million to pass from Peter's pocket into Paul's. Although this may at first be merely an individual misfortune, it will have repercussions on the wealth of society which the state has an interest in preventing, redressing or mitigating" (1844, pp. 226-7 [1952, p. 99]).
} 
Unlike the economist who is only concerned by public utility and the wealth of society, the state have to take into account the redistributive and indirect effects of the build or the improvement of a transport infrastructure since they may have long-term impacts on the wealth of society and so on the welfare of society and general interest. But what are the conditions necessary for the legislator to compensate the redistribution of wealth and the indirect effects of the build of a transport infrastructure?

\subsection{Which kinds of redistribution and indirect effects should be compensated by the state?}

For Dupuit, the distribution of wealth is determined by the law of supply and demand. This means that it results from human faculties, needs, and tastes (1861a, p. 601), or from what Dupuit names the "public" (Ibid). This may lead to "results that seem odd; a dancer or a singer might have wages much higher than the one of magistrate and of the general" (Ibid). However, the distribution of wealth might vary over time; the question arises as to whether, in such a perspective, state intervention to correct this would be justified. Dupuit's response is clear: if the state is not responsible for the evolution of the distribution of wealth among individuals in society, the legislator should not try to correct it. More precisely, for the engineer, redistributions of wealth among members of society may have three origins: nature, individual actions and the state's decisions (Poinsot, 2011, pp. 271-3). I will only focus on the latter two because they are the only ones that may be related to the issue of transport.

Redistributions of wealth may first result from the actions of individuals; for instance, when an individual introduces a new machine into the production process. As Dupuit claims it, inventions and innovations might imply major changes in the distribution of wealth among the members of the nation and "ruins some and increases the wealth of others" (1861a, p. 602). Dupuit never mentions the possibility for the state to compensate for the losses of the producer who has seen his (her) revenues collapse due to the entry of a competitor using a superior technology. For him, the actions of individuals which imply a redistribution of wealth are motivated by the search for profit and therefore have positive impacts on the 
wealth of society and so on the welfare of the nation. This argument applied to the field of transport leads to the conclusion that an innovation that call into question some interests should not, in Dupuit's view, be the object of any compensation.

Another source of redistribution of wealth is the action of the state. The legislator should be concerned about the effects of these redistributions of wealth on the welfare of society. But does it have to intervene in all cases? Dupuit's response is a negative one: compensation by the state is not required when the redistribution of wealth has no impact on the quantity of wealth and so on the welfare of society; on the other hand, it is necessary for the legislator to intervene when the redistribution of wealth have a long-term negative influence on the welfare of society.

But why, according to Dupuit, the way in which wealth is distributed among individuals is likely to have an impact on the quantity of wealth of society. The engineer does not provide any argument in his articles on the measurement of public utility (1844, 1849 and 1853). Elements appear in his book on free trade, La liberté commerciale (1861c), as well as in the rest of his work. He uses two arguments: the first relates to the impact of a redistribution of wealth on the moral responsibility of individuals; the second is the link between the merit and quality of an individual's work and its income.

First, a redistribution of wealth would decrease the moral responsibility of individuals, in particular for the poor. For instance, imagine that the construction of a transport infrastructure implies a redistribution of wealth to the benefit of the poor. According to the engineer, "misery is [...] a consequence of individual freedom; it is in our societies the punishment of misconduct, just as welfare is the reward of labor and foresight" (1861c, p. 489). The poor are poor because they have more children than their income permits. Then, a transport infrastructure which has the consequence to increase the income of the poor would have the effect of increasing the level of population, thus reducing the average wealth of society as well as its welfare. Indeed, "if one were able to improve their situation [of the poor] in an artificial way, they would increase the number of their children" (1865c, p. 374). 
Second, redistribution of wealth may reduce the quantity of wealth and the quality of products because it may reduce the relationship between an individual's income and its effort and the quality of his (her) work. This argument is not directly exposed by Dupuit but it derives from his position in a debate at Société d'Economie Politique which is a comparison between the ability of the state and larges companies to operate firms (Dupuit, 1862c). In his speech, he distinguishes different forms of firms (ordinary firms, collective industry and specific industry such as, for instance, railways and network industries) based on the link that exists between the work of an individual and the result of this work, his (her) wage. For Dupuit, the individual provides a most intense and quality work when his (her) wage is consistent with his (her) work (1862c, p. 584). In another debate concerning workers' associations, he rejects this type of organization because there is no link between the individual work and his (her) wage (Dupuit, 1863b, p. 765). This means that a redistribution of wealth may have negative impacts on the effort and the quality work provided by individuals by breaking the link between wage and the quality of the work of an individual. As a result, to prevent the decrease of the quantity of wealth in the long run, state should compensate the redistribution of wealth deriving from its decisions. But state should not intervene when this redistribution has no impacts on the quantity of wealth.

Thus, for Dupuit, two conditions are necessary to justify the intervention of the state in order to compensate a redistribution of wealth:

i. The state should be the cause of the redistribution of wealth among the members of society;

ii. This redistribution of wealth should have negative effects on the quantity of wealth and so on the welfare of society in the long run.

\section{Conclusion}

While there are many debates today on the relationships between equity considerations and $\mathrm{CBA}$, in this article, I analyze the thought of one precursor of the tradition of the engineereconomist tradition, Jules Dupuit, on the issue of the redistribution and indirect effects 
caused by transport policy and infrastructure. In particular, I show that, unlike the traditional reading of Dupuit, it is necessary to distinguish between general interest and public utility. These two concepts correspond to two different points of view - the legislator's point of view and the engineer-economist's point of view - which are at stake in his position on redistributions of wealth and indirect effects and the opportunity to integrate them into CBA and collective choices. For Dupuit, the engineer-economist should not take into account these issues because he is only concerned by public utility whereas the legislator have to take them into account and compensate them when the state is the cause of them and when they may have negative effects on the quantity of wealth in the long run. Then, redistribution and indirect effects should not be integrated into CBA whereas it should be taken into account for collective choices. In other words, in the case of project assessment, while CBA should only be concerned by the impacts which can be directly assigned to a project, the public decision maker should also consider indirect and redistribution effects that might have negative impacts on the wealth and welfare of society in the long run.

Dupuit's thought raises the issue of the place of CBA in collective choices. In particular, should we ask CBA to take into account all impacts of transport policies and infrastructure projects? Or, should CBA only focus on some of these effects? Without any doubt, Dupuit would prefer the latter. But, economic analysis might also help the legislator to analyze wealth redistribution and inequalities caused by transport projects and policies. 
References

Béraud, A. (2005). Richesse et Valeur : la contribution des économistes français du début du 19éme siècle. Economies et Sociétés, Cahiers de l'ISMEA, (36), pp. 1009-32. Available at:

http://halshs.archives-ouvertes.fr/docs/00/05/40/65/PDF/valeur_et_richesse_3.pdf.

Béraud, A. (2006). Walras et les ingénieurs économistes français : Des Eléments d'économie politique pure au Traité d'économie pure. Communication at the $5^{\text {th }}$ Conference of the Association Internationale Walras. Available at: http://www.ucergy.fr/beraud/ing.pdf.

Boiteux, M. (1994). Transports : pour un meilleur choix des investissements. Commissariat général du Plan.

Boiteux, M. (2001). Transports : choix des investissements et coût des nuisances. Commissariat général du Plan, Paris, La Documentation française.

Bordas, L. (1847). De la mesure de l'utilité des travaux publics. Annales des Ponts et Chaussées, 13; reproduced in M. de Bernardi (1934), De l'utilité et de sa mesure. Écrits choisis et republiés par Mario de Bernardi. Torino (Italie) : Pozzo Fratelli, pp. 6796.

Browne, D. \& Ryan, L. (2011). Comparative analysis of evaluation techniques for transport policies. Environmental Impact Assessment Review, 31(3), pp. 226-233.

Chatzis, K. (2009). Jules Dupuit, ingénieurs des Ponts et Chaussées. In Y. Breton \& G. Klotz (eds.) (2009), Vol. 1, pp. 615-92.

Di Ciommo, F. \& Shiftan, Y. (2017). Transport equity analysis. Transport Reviews, 37(1), pp. 139-151.

Dupuit, J. (1844) [1952]. De la mesure de l'utilité des travaux publics. English translation by R. H. Barback 1952. On the measurement of the utility of public works. International Economic Papers, 2, pp. 83-110.

Dupuit, J. (1849) [1962]. De l'influence des péages sur l'utilité des voies de communication. English translation by E. Henderson 1962. On Tolls and Transport Charges. International Economic Papers, 11, pp. 7-31.

Dupuit, J. (1853). De l'utilité et de sa mesure. De l'utilité publique. Journal des économistes, reproduced in Breton \& Klotz (eds.) (2009), Vol. I, pp. 309-334.

Dupuit, J. (1855). Des fondements du droit de propriété. Journal des économistes, intervention at Société $d^{\prime}$ économie politique, meeting of January, $5^{\text {th }} 1855$; reproduced in Breton \& Klotz (eds.) (2009), Vol. II, pp. 564-8.

Dupuit, J. (1861a). Du principe de propriété. Le juste - L'utile. Journal des économistes, reproduced in Breton \& Klotz (eds.) (2009), Vol. II, pp. 583-612.

Dupuit, J. (1861b). Du principe de propriété. Le juste - L'utile (suite et fin). Journal des économistes, reproduced in Breton \& Klotz (eds.) (2009), Vol. II, pp. 613-40.

Dupuit, J. (1861c). La liberté commerciale, son principe et ses conséquences. Paris: Guillaumin ; reproduced in Breton \& Klotz (eds.) (2009), Vol. II, pp. 414-537.

Dupuit, J. (1862a). De la justice au point de vue économique et relativement à la propriété. Journal des économistes, intervention at Société d'économie politique, meeting of October, $6^{\text {th }} 1862$; reproduced in Breton \& Klotz (eds.) (2009), Vol. II, pp. 641-5.

Dupuit, J. (1862b). Le gouvernement doit-il intervenir dans les coalitions soit de patrons, soit d'ouvriers, ayant pour but d'obtenir une diminution ou une augmentation 
de salaire ?. Journal des économistes, intervention at Société d'économie politique, meeting of June, $5^{\text {th }} 1862$; reproduced in Breton \& Klotz (eds.) (2009), Vol. II, pp. 73741.

Dupuit, J. (1862c). Les compagnies sont-elles plus aptes que l'Etat à exercer une industrie, surtout lorsque cette industrie est un monopole ? S'il y a possibilité de concilier les grandes compagnies avec la concurrence. Journal des économistes, intervention at the Société $d^{\prime}$ économie politique, meeting of December, $5^{\text {th }} 1861$; reproduced in Breton \& Klotz (eds.) (2009), Vol. I, pp. 583-9.

Dupuit, J. (1863a). Quelle doit être l'attitude de l'Etat à l'égard des coalitions de patrons ou d'ouvriers ? Quelles sont les combinaisons fondées sur l'initiative privée qui peuvent conjurer les inconvénients de ces coalitions ?. Journal des économistes, intervention at the Société internationale des études pratiques d'économie sociale, meeting of December, $20^{\text {th }} 1863$; reproduced in Breton \& Klotz (eds.) (2009), Vol. II, pp. 743-6.

Dupuit, J. (1863b). Les associations ouvrières Journal des économistes, intervention at the Société d'économie politique, meeting of December, $5^{\text {th }} 1863$; reproduced in Breton \& Klotz (eds.) (2009), Vol. II, pp. 763-6.

Dupuit, J. (1865). Des causes qui influent sur la longueur de la vie moyenne des populations. Journal des économistes, reproduced in Breton \& Klotz (eds.) (2009), Vol. II, pp. 34777.

Dupuit, J. (2009d). L'économie politique est la science de la société. Unpublished manuscript, reproduced in Breton \& Klotz (eds.) (2009), Vol. II, pp. 47-61.

Ekelund, R. B. \& Hébert, R. F. (1999). Secret origins of modern microeconomics. Dupuit and the engineers. Chicago: University of Chicago Press.

Etner, F. (1983). Note sur Dupuit. Revue économique. 34(5), pp. 1021-35.

Etner, F. (1987). Histoire du calcul économique en France. Paris: Economica.

Grall, B. \& Vatin, F. (1998). La machine et l'impôt : Jules Dupuit, l'économie politique et la mécanique industrielle. In F. Vatin, Economie politique et économie naturelle chez Antoine-Augustin Cournot, Paris: PUF, pp. 398-425.

Grall, B. \& Vatin, F. (2002). La machine et l'impôt : Jules Dupuit, l'économie politique et la mécanique industrielle. In J. Simonin \& F. Vatin (eds.) (2002), pp. 39-60.

Grall, B. (2004). Economie des forces et production d'utilité. La pensée gestionnaire des ingénieurs des ponts (1831-1891). Edition de la thèse de Bernard Grall (1962-1997). Rennes: Presses universitaires de Rennes.

Grall, B. \& Vatin, F. (2016). Machinery and taxation: Jules Dupuit, political economy and industrial mechanics. In J.-P. Simonin \& F. Vatin (eds.) (2016), pp. 47-80.

Grall, B. (2004). Economie des forces et production d'utilité. La pensée gestionnaire des ingénieurs des ponts (1831-1891). Edition de la thèse de Bernard Grall (1962-1997). Rennes: Presses universitaires de Rennes.

Litman, T. (2002). Evaluating Transportation Equity. World Transport Policy \& Practice (http://ecoplan.org/wtpp/wt_index.htm), 8(2), Summer, pp. 50-65.

Maneschi, A. (1996). Jules Dupuit: A sesquicentennial tribute to the founder of benefit-cost analysis. The European Journal of the History of Economic Thought, 3(3), pp. 411-32.

Martens, K. (2011). Substance precedes methodology: on cost-benefit analysis and equity. Transportation, 38(6), pp. 959-74. 
Mosca, M. (1998). Jules Dupuit, the French 'ingénieurs économistes' and the Société d'Economie Politique. In G. Faccarello (Éd.), Studies in the History of French Political Economy. Londres: Routledge, pp. 254-83.

Poinsot, P. (2010). The foundations of justice in Jules Dupuit's thought. European Journal of the History of Economic Thought, 17 (4), pp. 783-812.

Poinsot, P. (2011). La relecture de l'œuvre de Jules Dupuit à l'aune de la notion de bien-être: intérêt général, bien-être et utilité publique. PhD diss., University of Paris 1 Panthéon-Sorbonne.

Poinsot, P. (2016). Jules Dupuit and the railroads : what is the role of the state ? ". Journal of the History of Economic Thought, 38(2), pp. 189-209.

Quinet, E. (2013). Evaluation socioéconomiques des investissements publics. Commissariat général à la stratégie et à la prospective.

Reverdy, G. (2002). Jules Dupuit, 1804-1866, ingénieur en chef de Maine-et-Loire, 18441850. In J.-P. Simonin and F. Vatin (eds.) (2002), pp. 15-36.

Reverdy, G. (2016). Jules Dupuit, 1804-1866, Chief Engineer of Maine-et-Loire, 1844-1850. In J.-P. Simonin \& F. Vatin (eds.) (2016), pp. 25-44.

Sagot-Duvauroux, D. (2002a). Controverse sur le 'monautopole': Jules Dupuit face au droit d'auteur. In J.-P. Simonin and F. Vatin (eds.) (2002), pp. 117-26.

Sagot-Duvauroux, D. (2002b). Préface. In D. Sagot-Duvauroux, Les majorats littéraires: Ia propriété intellectuelle c'est le vol!, Dijon: les presses du réel, pp. 9-27.

Sagot-Duvauroux, D. (2016). The 'monautopoly' controversy: Dupuit and the issue of intellectual property. In J.-P. Simonin \& F. Vatin (eds.) (2016), pp. 123-37.

Sigot, N. (2010). Utility and justice: French liberal economists in the nineteenth century. The European Journal of the History of Economic Thought, 17 (4), pp. 759-92.

Simonin, J.-P. \& Vatin, F. (eds.) (2002). L'œuvre multiple de Jules Dupuit (1804-1866). Calcul d'ingénieur, analyse économique et pensée sociale. Angers: Presses Universitaires d'Angers.

Simonin, J.-P. \& Vatin, F. (eds.) (2016). The Worls of Jules Dupuit. Engineer and Economist of the French XIX ${ }^{\text {th }}$ Century. Saint-Denis: EDI-GESTION.

Smith, C. O. (1990). The Longest Run: Public Engineers and Planning in France. The American Historical Review, 95(3), pp. 657-692.

Thomopoulos, N.; Grant-Muller, S. \& Tight, M. R. (2009). Incorporating equity considerations in transport infrastructure evaluation: Current practice and a proposed methodology. Evaluation and Program Planning, 32(4), pp. 351-59.

Vatin, F. (2002). La morale utilitaire de Jules Dupuit. In J.-P. Simonin and F. Vatin (eds.) (2002), pp. 91-116.

van Wee, B. (2011). Transport and ethics: Ethics and the evaluation of transport policies and projects. Cheltenham: Edward Elgar. 